\title{
Influence of Students' Perceived Ease of Use, Perceived Usefulness and Time Spent Towards Students' Continuance Intention Using MOOC Among Public University Students
}

\author{
Aisha Aminu Daneji ${ }^{\text {, }}$ Ahmad Fauzi Mohd Ayub ${ }^{\text {b }}$, Wan Marzuki Wan Jaafar a , \\ Mas Nida Md. Khambari ${ }^{\text {a }}$ \\ ${ }^{\text {a }}$ Faculty of Educational Studies, Universiti Putra Malaysia, 43400 Serdang Selangor Darul Ehsan \\ ${ }^{b}$ Laboratory of Ethnomathematics and Didactics, Institute for Mathematical Research, Universiti Putra Malaysia, \\ 43400 Serdang Selangor Darul Ehsan
}

Corresponding e-mail: $\underline{\text { aishadaneji@gmail.com }}$

\begin{abstract}
With the development of technology and internet, more and more public universities in Malaysia has put in their efforts and investment in MOOC. The benefits of MOOC cannot be maximized, as there is high enrolment but low courses completion rate. The aim of this paper is to explore the influence perceived usefulness, perceived ease of use and time spent towards MOOC continuance intention among Higher Education students. Data from 447 students in Malaysian Public Universities was collected and multiple regression approach was adopted. The results revealed that perceived usefulness and perceived ease of use have a strong significant correlation with MOOC continuance intention while time spent has no significant correlation with MOOC continuance intention. The findings provide insights to MOOC providers in planning improved continuance intention towards using MOOCs.
\end{abstract}

Keywords: $\quad$ MOOC, Continuance Intention, Higher Education

\section{INTRODUCTION}

Technology has brought many changes in our everyday life and education is one of the fields where the impact can be noticed (Ferrari, Brecko \& Punie, 2014). With digital technologies and the Internet growing rapidly, new ways of learning were created (Redecker \& Johannessen, 2013). The developments in technology had reached a stage where new terms and concepts were introduced in the education field (Baleighi-Zadeh et al., 2014). Education is an important area, where the Internet is used widely to promote and improve the quality of the learning process (Alkhanak \& Azmi, 2011). The increase utilization of e-learning in advanced higher education has led to the establishment of Massive Open Online Courses (MOOCs) that seemed to be a very reasonable outcome of digitization (Haggard, 2013; Clarke, 2013). MOOCs have lately pulled in the attention of many individuals around the globe (Rai \& Chunrao, 2016) through various MOOC providers such as Coursera, edX, Udacity, and others (Fowler, 2013). MOOCs are now changing the face of education by providing ways in which all concepts of learning are employed by hundreds of universities (Teplechuk, 2013) and are offered in an online domain with a clear difference from the past online education (Alraimi et al., 2015).
There were several studies where the contributions of MOOC were stated (Ridwan, 2015). Krause and Lowe (2014) presented a useful synthesis of the assertions made about the promise and issues of MOOCs. They revealed that MOOCs have the potential to challenge the closed and privileged nature of academic knowledge in traditional universities. Perceived usefulness was realized to be associate with satisfaction and continuance intention in various studies. The study by Premkumar and Bhattacherjee (2008), found that just as perceived usefulness was the predictor of intention in TAM, it would continue to be a strong predictor of continuance intention compared to satisfaction when TAM merge with ECT. The relative power of usefulness justified its part as a driver in continuation of choices, especially when compared to the usefulness value over hedonic value (Premkumar \& Bhattacherjee, 2008). Bhattacherjee (2001) reported an individual was expected to accept continued intention to use when such usage was perceived to be valuable.

Previous studies had found the positive connection between PEOU and information technology acceptance (Dishaw \& Strong, 1999; Gefen et al., 2003; Venkatesh, 2000). There were also several studies that supported the positive association of PEOU with PU (Davis, 1989; Hsu \& 
$\mathrm{Lu}, 2004)$. PEOU was discovered to have a great effect on satisfaction and continuance intention to operate an information system (IS) (Bhattacherjee, 2001). The positive impact of PEOU on continuance intention to use technology was supported by many studies such as the intention to use the e-govt website (Wangpipatwong et al., 2008), Facebook (Sibona et al., 2012) and others.

Bhattacharjee (2001) had built up the Expectation-Confirmation Model (ECM) by extending the Expectation-Confirmation Theory (ECT) with Technology Acceptance Model (TAM). The ECM theorizes that perceived usefulness along with confirmation of expectations from the initial use of the products or service lead to user satisfaction and confirmation that likewise influence perceived usefulness (Bhatacherjee, 2001). The Expectation Confirmation Theory proposed by Oliver (1980) had shown that perceived ease of use influenced perceived usefulness. Perceived ease of use had been considered and proved in TAM that it could improve users' continuance usage (Davis, 1989; Venkatesh et al., 2003).

\section{OBJECTIVE OF THE STUDY}

The study aimed to explore the influence of students' perceived ease of use, perceived usefulness and time spent towards students' continuance intention in using MOOC.

\section{METHODOLOGY}

Correlational Survey research design was chosen for the current research to predict factors influencing MOOC continuance intention among undergraduate students. In this study, population refers data collected among 447 undergraduate students in Malaysian public Universities registered in putraMOOCs during their period of study to learn online. Data was gathered using an online questionnaire which appears to be the appropriate way to collect data for this study since putraMOOC is an online course and students cannot be reach through paper-based surveys.

For the study, the researchers developed an instrument consisting of frequence time spent on MOOC, perceived usefulness, perceived ease of use, and MOOCs continuance intention. The time spent on using putraMOOC data was measure by asking the respondents "On average, how much time do you spend each time you log in to PutraMOOC? Perceived usefulness examine the level to which students believe that using PutraMOOC will improve their learning performance. Eight items are used to measure this construct adapted from Davis (1986), Pituch and Lee (2006), and Sánchez and
Huerous (2010). Meanwhile, perceived ease of use will assess the degree to which students believe that using PutraMOOC will be free of effort. Five items adapted from Davis, (1989) and three from Sánchez and Huerous, (2010) were used to measure the construct of perceived ease of use. Lastly, students' continuance intention towards using MOOC aims at assessing the intention of students to continue using putraMOOC. This construct consists of six items which three items adapted each from Bhattacherjee (2001) and Roca et al., (2006).

All the dependent and independent variables were found to be reliable instruments to measure all the variables studied in a pilot study that had been conducted on 32 undergraduate students from UPM enrolled in putraMOOC. The reliability coefficient, Cronbach Alpha, for each subscale ranged from 0.7 to 0.8 (Table 1). The internal consistency of the questionnaire is regarded as an acceptable instrument since all values exceed 0.6 according to Leech et al., (2008).

Table 1: Reliability of the Constructs

\begin{tabular}{lcc}
\hline \multicolumn{1}{c}{ Construct } & $\begin{array}{c}\text { No. } \\
\text { Items }\end{array}$ & $\begin{array}{c}\alpha: \text { Pilot Study } \\
{[\mathrm{n}=32]}\end{array}$ \\
\hline Perceived Usefulness & 8 & 0.738 \\
Perceived Ease of Use & 8 & 0.762 \\
MOOC Continuance & 6 & 0.797 \\
Intention & & \\
\hline
\end{tabular}

\section{RESULTS AND DISCUSSION}

The discussion will be based on the four variables studied for this study. In this study, three independent variables, which are perceived ease of use, perceived usefulness and hours spent were used to predict students' students' continuance intention towards using MOOC. The respondents were undergraduate students at Malaysian public universities who enrolled in PutraMOOC for one of the university course. The time spent on using putraMOOC for every hour in a day shows that $39.7 \%$ of the respondents reported they spent one to two hours using putraMOOC each day, while $41.6 \%$ of respondents spent three to four hours daily on using putraMOOC. $14.9 \%$ of respondents used putraMOOC for five to six hours, and only 14 $(3.8 \%)$ of the respondents reported to have used putraMOOC for more than six hours in a day. Overall mean for hours spent on putraMOOC per day is $1.33(\mathrm{SD}=.806)$.

The overall mean for the perceived usefulness using putraMOOC is 3.73 ( $\mathrm{SD}=0.774$ ) shows that respondents have a positive perception that using putraMOOC would improve their learning 
performance. For perceived ease of use of putraMOOC, the mean value is $3.65(\mathrm{SD}=0.715)$ meaning that the respondents perceived putraMOOC would be easy to use. Overall, the mean for MOOC continuance intention is $3.53(\mathrm{SD}=0.832)$ exhibiting that the respondents have the intention to continue using putraMOOC.

Table 2 : Mean and standard deviation of the variables

\begin{tabular}{lcc}
\hline \multicolumn{1}{c}{ Construct } & Mean & $\begin{array}{l}\text { Standard } \\
\text { Deviation }\end{array}$ \\
\hline Time Spent & 1.33 & .806 \\
Perceived Usefulness & 3.67 & .749 \\
Perceived Ease of Use & 3.58 & .671 \\
MOOC Continuance & 3.48 & .800 \\
Intention & & \\
\hline
\end{tabular}

Table 3 shows the Pearson correlation coefficients between perceived ease of use, perceived usefulness and time spent and MOOC Continuance Intention. There was a positive correlation between perceived ease of use $(\mathrm{r}=.721 ; \mathrm{p}<.001)$, perceived usefulness $(\mathrm{r}=.747 ; \mathrm{p}<.001)$, and time spent $(\mathrm{r}=.129 ; \mathrm{p}<$ $.001)$ with students' MOOC Continuance Intention.

Table 3: Correlation Coefficients Between Perceived Ease of Use, Perceived Usefulness and Time spent towards students' continuance intention in using MOOC.

\begin{tabular}{llll}
\hline & $\begin{array}{l}\text { Perceived } \\
\text { ease of use }\end{array}$ & $\begin{array}{l}\text { Perceived } \\
\text { usefulness }\end{array}$ & $\begin{array}{l}\text { Time } \\
\text { spent }\end{array}$ \\
\hline $\begin{array}{l}\text { Continuance } \\
\text { intention } \\
\text { towards using }\end{array}$ & $\mathrm{p}<.001$ & $\begin{array}{l}.747^{* *} \\
\mathrm{p}<.001\end{array}$ & $\begin{array}{l}.129 * * \\
\text { MOOC }\end{array}$ \\
\hline
\end{tabular}

To identify factors that influence students' continuance intention using MOOC, a stepwise multiple regression was conducted. Table 4 indicates the statistics test of significance was at the 0.05 $\left(\mathrm{F}_{(3,443)}=232.445, \mathrm{p}=0.000\right)$.

Table 4 : ANOVA

\begin{tabular}{lcllll}
\hline & Sum of & & Mean & & \\
& Squares & df & Square & F & Sig. \\
\hline Regression & 172.468 & 3 & 57.489 & 232.45 & .000 \\
Residual & 109.565 & 443 & 0.247 & & \\
\hline Total & 282.033 & 446 & & & \\
\hline
\end{tabular}

Table 5 shows the multiple correlation coefficients was .782, indicating approximately $61.2 \%$ of the variance of the students' continuance intention using MOOC accounted for by perceived ease of use, perceived usefulness and time spent.
Table 5 : Model Summary

\begin{tabular}{lllllll}
\hline $\mathrm{R}$ & $\mathrm{R}^{2}$ & Adj R $^{2}$ & $\mathrm{~F}$ & 1 & 2 & $\begin{array}{l}\text { Sig.F } \\
\text { Change }\end{array}$ \\
\hline 0.7 & 0.6 & & 232.44 & & & \\
82 & 12 & 0.609 & 5 & 3 & 3 & .000 \\
\hline
\end{tabular}

Based on the results presented in Table 6 , the most significant contributor to students' continuance intention was perceived usefulness. This factor contributed $55.8 \%$ of the variance in students' continuance Intention. Perceived ease of use was also identified as one of the significant contributors and explained $51.9 \%$ of the variance in students' continuance intention. However, time spent was not a contributor in this study.

Table 6: Coefficient

\begin{tabular}{lccccc}
\hline & & & & & \\
& B & Std. Error & Beta & & Sig. \\
\hline Const. & 0.086 & 0.134 & & 0.638 & .524 \\
PU & 0.486 & 0.05 & 0.458 & 9.644 & .000 \\
PEOU & 0.431 & 0.056 & 0.363 & 7.705 & .000 \\
T S & 0.053 & 0.03 & 0.054 & 1.789 & .074 \\
\hline
\end{tabular}

\section{DISCUSSION \& CONCLUSION}

Massive Open Online Course (MOOC) is a new online medium for course delivery and learning. It enables thousands of learners to participate in the same course with high-quality content and interactive tools for learning. This study was to investigate factors that influence MOOC continuance intention among higher education students. The selected factors were perceived usefulness, perceived ease of use and time spent using MOOC. The study shows that putraMOOC is useful to the students whereby they think that using putraMOOC would have a positive effect on their learning and also useful for their online learning. It also appears to be that the respondents have the intention to continue using putraMOOC as they strongly recommend others to use it. Besides, they intend to continue using putraMOOC rather than discontinue its use.

The Pearson's correlation analysis indicated that perceived ease of use, perceived usefulness and time spent have significant relationships with MOOC continuance intention. This signifies that the more students find MOOC useful and easy to use, the more likely they would continue using MOOC. Further analysis concluded that perceived usefulness and perceived ease of use influence students' 
continuance intention of MOOC use among students in Malaysian Public Universities.

The influence of perceived usefulness on MOOC continuance intention is inline with the findings of Mouakket (2015) who observed that it was the antecedent of user continuance intention with regards to facebook. The above findings are also in accordance the results produced by Alraimi et al., (2015), as well as $\mathrm{Wu}$ and Chen (2017), who observed that perceived usefulness has a positive effect on intention to continue using MOOCs. This indicates that when students believe that learning through MOOCs will be useful and can improve their knowledge, they will prefer to continue using MOOCs.

Meanwhile, the contribution by the perceived ease of use towards MOOC continuance intention reflected the previous results obtained by Bhattacherjee and Barfar (2011), which revealed that perceived ease of use has a significant effect on continuance intention with an information system. In the same manner, Chang et al., (2015), verified that the continuance intention of technology or system is influence by perceived ease of use. With this, it shows that students will continue to use MOOC as far as they find it easy to use and no much effort needed.

Conclusively, the continuance intention in using MOOC showed the existence of the significant influence of perceived usefulness and perceived ease of use on MOOC continuance intention. Hence, for an increase in the continuance use of MOOC at Public Universities in Malaysia, the MOOC providers need to ensure the quality of the courses and the MOOC platforms will be taken into due consideration.

\section{REFERENCES}

Alkhanak, S.A.A.K., \& Azmi, I. A. G. (2011). University Student Information Technology Experience and Its Role Towards e-learning orientation. New Educational Review, 24(2), 231-242.

Alraimi, K. M., Zo, H., \& Ciganek, A. P. (2015) Understanding the MOOCs continuance: The role of openness and reputation. Computer \& Education, 80(2), 28-38.

Baleghi-Zadeh, S., Ayub, A. F. M., Mahmud, R., \& Daud, S. M. (2014). Learning Management System Utilization among Malaysian Higher Education Students: A Confirmatory Factor Analysis. Journal of Education \& Human Development, 3(1), 369-386.

Bhattacherjee, A. (2001). Understanding information systems continuance: an expectation- confirmation model. MIS Quarterly, 25(3), 351370.

Bhattacherjee, A., \& Barfar, A. (2011). Information technology continuance research: current state and future directions. Asia Pacific Journal of Information Systems, 21(2), 1-18.

Chang, C. C., Hung, S. W., Cheng, M. J., \& Wu, C. Y. (2015). Exploring the intention to continue using social networking sites: The case of Facebook. Technological Forecasting and Social Change, 95, 48-56.

Clarke, T. (2013). The advance of the MOOCs The impending globalization of business education?. Education Training, 55(4/5), 403413.

Davis, F. D. (1989). Perceived usefulness, perceived ease of use, and user acceptance of information technology. MIS Quarterly, 13(3), 319-340.

Dishaw, M. T., \& Strong, D. M. (1999). Extending the technology acceptance model with tasktechnology fit constructs. Information \& management, 36(1), 9-21.

Fowler, G. (2013). Most MOOC Users WellEducated, Study Finds. The Wall Street Journal. Retrieved November, 2015 from http://goo.gl/XnrnL7.

Gefen, D., Karahanna, E., \& Straub, D. W. (2003). Trust and TAM in online shopping: An integrated model. MIS Quarterly, 27(1), 51-90.

Haggard, S. (2013). The maturing of the MOOC. BIS Research Paper Number 130. London: Department for Business.

Hair, J. F., Black, W. C., Babin, B. J., \& Anderson, R. E. (2010), Multivariate Data Analysis (7th ed.). New Jersey: Prentice-Hall.

Hsu, C. L., \& Lu, H. P. (2004). Why do people play on-line games? An extended TAM with social influences and flow experience. Information \& management, 41(7), 853-868.

Krause, S. D., \& Lowe, C. (Eds.). (2014). Invasion of the MOOCs: The promises and perils of massive open online courses. South Carolina : Parlor Press.

Leech, N. L., \& Barrett, K. C. Morgan. GA (2008). SPSS for intermediate statistics: Use and interpretation. New York : Routledge

Mouakket, S. (2015). Factors influencing continuance intention to use social networksites: The Facebook case. Computers in Human Behavior, 53(C), 102-110.

Pallant, J. (2013). SPSS survival manual: A step by step guide to data analysis using IBM SPSS Maidenhead: McGraw-Hill.

Pituch, K. A., \& Lee, Y. K. (2006). The influence of system characteristics on e-learning use. Computers \& Education, 47(2), 222-244. 
Premkumar, G., \& Bhattacherjee, A. (2008). Explaining information technology usage: A test of competing models. Omega, 36(1), 64-75.

Rai, L., \& Chunrao, D. (2016). Influencing factor of success and failure in MOOC and general analysis of learner behavior. International Journal of Information and Education Technology, 6(4), 262 -268

Redecker, C., \& Johannessen, O. (2013). Changing assessment-Towards a new assessment paradigm using ICT. European Journal of Education, 48(1), 79-96.

Ridwan, S. M. (2015). Application of Massive Online Open Courses in Tertiary Institutions in Nigerian: Prospects and Challenges. International Journal of Emerging Technology and Advanced Engineering. 5(1), 81-87

Roca, J. C., Chiu, C. M., \& Martínez, F. J. (2006). Understanding e-learning continuance intention: An extension of the Technology Acceptance Model. International Journal of human-computer studies, 64(8), 683-696.

Sánchez, R. A., \& Hueros, A. D. (2010). Motivational factors that influence the acceptance of Moodle using TAM. Computers in Human Behavior, 26(6), 1632-1640.

Sibona, C., \& Choi, J.-H. (2012). Factors Affecting End-User Satisfaction on Facebook. Proceedings of the sixth international conference on weblogs and social media (pp. 575-578). Dublin: The AAAI Press, Palo Alto, California.

Teplechuk, E. (2013). Emergent models of Massive Open Online Courses: an exploration of sustainable practices for MOOC institutions in the context of the launch of MOOCs at the University of Edinburgh. Master Dissertation, University of Edinburgh.

Venkatesh, V., \& Davis, F. D. (2000). A theoretical extension of the technology acceptance model: Four longitudinal field studies. Management Science, 46(2), 186-204.

Venkatesh, V., Morris, M. G., Davis, G. B., \& Davis, F. D. (2003). User acceptance of information technology: Toward a unified view. MIS Quarterly, 27(3), 425-478.

Wangpipatwong, S., Chutimaskul, W., \& Papasratorn, B. (2008). Understanding Citizen's Continuance Intention to Use e-Government Website: a Composite View of Technology Acceptance Model and Computer Self Efficacy. Electronic Journal of $e$ Government, 6(1). 55 - 64

Wu, B., \& Chen, X. (2017). Continuance intention to use MOOCs: Integrating the technology acceptance model (TAM) and task technology fit (TTF) model. Computers in Human Behavior, 67, 221-232. 